\title{
Quality assurance of the serologic diagnosis of Chagas' disease
}

\author{
Estela N. Cura ${ }^{1}$ and Elsa L. Segura ${ }^{2}$
}

ABSTRACT A quality assurance program of the Chagas' disease laboratory network of Argentina has been conducted by the National Reference Center since 1988, with the aim of assessing the reliability of serologic test results. Chagas' disease is endemic in Argentina, but the prevalence of seropositivity for Trypanosoma cruzi among 18- to 20-year-old men decreased from $5.8 \%$ in 1981 to 1.8\% in 1994. About 600 laboratories form the Chagas' disease laboratory network, with main central laboratories in each of the 24 provinces in Argentina. The quality assurance program promotes regular use of good laboratory practice and internal and external quality control to improve performance of the participants; it also provides technical assistance and guidelines. Eventual corrective measures are discussed in workshops. Results of the first external evaluation by proficiency testing of serum panels and confirmation of results for 58 of the main laboratories reveal that from 1988 to 1994 the rate of agreement has increased.

Chagas' disease is caused by the flagellate protozoan Trypanosoma cruzi. The disease is endemic in 17 American countries, where it is estimated that 16-18 million people are infected with the parasite, and another 90 million are at risk of infection (1). The infection is transmitted mainly through a triatomine vector. Interhuman transmission is second in sanitary importance and may occur through blood

\footnotetext{
1 Instituto Nacional de Parasitología "Doctor Mario Fatala Chaben," Ministerio de Salud y Acción Social, (1063) Buenos Aires, Argentina. Mailing address: Estela N. Cura, Instituto Nacional de Parasitología "Doctor Mario Fatala Chaben," Ministerio de Salud y Acción Social, Av. Paseo Colón 568, (1063) Buenos Aires, Argentina.

2 Member of the "Carrera del Investigador Científico y Tecnológico," CONICET, Buenos Aires, Argentina. Administración Nacional de Laboratorios e Institutos de Salud "Dr. Carlos G. Malbrán," Ministerio de Salud y Acción Social, Buenos Aires, Argentina.
}

transfusion (2), from mother to child $(3,4)$, and through organ transplantation (5).

Laboratory diagnosis is done by demonstrating the presence of the parasite-e.g., xenodiagnosis or the Strout method $(6,7)$-and is efficient in the acute phase of infection when the sensitivity is about $100 \%$; after a few weeks, efficiency decreases to less than $50 \%$. Use of polymerase chain reaction, a more sensitive method that can detect parasite DNA, is currently under study (8). Furthermore, the onset of infection is usually unnoticeable and is followed by a long asymptomatic period (range: 5-15 years). Thus, other methods are needed to diagnose the latent and chronic phases of infection, such as detecting specific antibodies to T. cruzi in the patients' serum $(9,10)$.

Many serologic techniques have been developed to detect T. cruzi anti- bodies, including complement fixation $(11,12)$, direct agglutination (DA), indirect hemagglutination (IHA) $(9,10$, 12), indirect immunofluorescence (IIF) (13), and enzyme-linked immunosorbent assay (ELISA) $(12,14,15)$. The parasite antigens used in these methods vary widely, from whole cells (IIF and DA) to crude cell extracts (IHA and ELISA), to defined molecules or peptides (ELISA) (15-17).

The sensitivity of the tests varies between $99 \%$ and $99.8 \%(9,10,18)$; when two or three tests are performed simultaneously, the sensitivity ranges from $99.7 \%$ to $100 \%(18)$. Their specificity (false-positive results from nonT. cruzi-infected individuals) ranges from $2.11 \%$ to $2.59 \%(9,18)$. In relation to other diseases such as malaria, amebiasis, and tuberculosis, the only crossreactions observed were with Leishmania and Trypanosoma rangeli $(9,18)$. 
Many efforts have been directed toward standardizing serologic methods $(12-14,16,19,20)$ and reagents (15-17), and it has been recommended that at least two serologic tests be used to confirm a diagnosis $(2,19)$. No systematized and overall quality control programs are currently being conducted in Chagas serology, even though the validity of laboratory results always depends on the quality of conditions before, during, and after the serologic tests are performed $(21,22)$.

Since 1987 we have carried out a quality assurance program with the Chagas' disease laboratory network by promoting good laboratory practice, using internal and external quality control, and giving technical assistance and procedure guidelines (23). The aim of the program is to improve the performance of participating laboratories and to assess the reliability of the results obtained with serology testing. In relation to the accuracy of the national reference laboratory itself, a South American group (Argentina, Bolivia, Brasil, Chile, Paraguay, and Uruguay) has been working since 1992 with an international reference serum panel for the control of Chagas serology.

We report here the results of proficiency tests conducted by the National Reference Center (NRC) for Chagas' disease in Argentina since 1988 and performed with 58 main laboratories belonging to the Chagas' disease laboratory network.

\section{MATERIALS AND METHODS}

Two materials were used to evaluate the performance of participating laboratories: proficiency panels and sera for the confirmation of results.

\section{Proficiency panels}

Serum samples were collected from about 100 infected and noninfected patients in the daily routine of clinical and laboratory diagnosis in the NRC for Chagas' disease in Argentina. These sera were tested by three different serologic tests performed at the same time: $\operatorname{IHA}(12,16), \operatorname{IIF}(13,16)$, and ELISA $(12,15,16)$.

\section{Sera classification criteria}

Serum samples were classified as nonreactive when all three serologic tests gave negative results against $T$. cruzi antigens and as reactive when all three tests were positive. The cutoff titer of IHA and IIF tests was 1/32; for ELISA the cutoff was an optical density (OD) of 0.200 . Reactive serum samples were classified as highly reactive when they showed 1/128 or higher titers for IHA and IIF tests and an OD higher than 0.300 for ELISA. Serum samples were classified as weakly reactive when they showed titers for IHA and IIF between 1/32 and 1/64 and an OD for ELISA ranging from 0.200 to 0.300 .

\section{Pooling and conditioning of panel samples}

The sera were pooled into three groups-nonreactive, highly reactive, and weakly reactive-with no more than 10 samples per group.

As a biosecurity measure, sera were tested for hepatitis B surface antigen and then inactivated at $56^{\circ} \mathrm{C}$ for 30 minutes. The samples were filtered through a membrane filter (pore size: $0.45 \mu \mathrm{m}$ ), fractionated in glass containers, and lyophilized. Coded samples were then distributed for the NRC with instructions for processing them $(21,23,24)$.

\section{Sera for confirmation of results}

During 1989, 1990, and 1994 the participating peripheral laboratories sent 40 to 200 tested serum samples to the NRC for confirmation of results. Approximately $50 \%$ of each group of sera consisted of specimens with reactivity to T. cruzi. Samples were preserved in buffered glycerin and stored at room temperature until shipment (25). They were then air-mailed to the NRC, where they arrived within 7 days. The quality of individual specimens on arrival was scored from "very good" to "not suitable for diagnosis" because of contamination, lack of proper identification, or poor conditioning.

\section{Design of the Quality Assurance Program}

Experiments were devised for the laboratory network in Argentina as part of a quality assurance program for the serologic diagnosis of Chagas' disease. The program included activities performed by the NRC and 58 other laboratories. The NRC is in charge of the normativeness of diagnosis $(19,23)$, standardization and control of reagents, training and updating of laboratory personnel (12), and evaluation of laboratory performance. The network laboratories are in charge of establishing internal quality control programs.

Internal quality control program. Laboratories were asked to establish internal programs to systematize controls including personnel training, selection of analytical methods, and control of reagents, equipment, and procedures. The NRC provided technical assistance for these activities, and a quality control procedure guideline (23) was distributed as well.

To validate the entire analytical process, daily aliquots of reactive and nonreactive control sera were analyzed together with samples from routine trials, and control curves were plotted. IHA and IIF titers were plotted as logarithms to the base 2 . Titers are the reciprocal of the highest serial serum dilution giving a reactive result on the test (26). For ELISA, ODs were plotted. According to acceptance criteria, the daily result of the reactive control sera should fall within the arithmetic mean \pm 2 standard deviations. Both parameters were computed with at least 30 continuous daily measures $(21,22)$. Nonreactive control sera must always be nonreactive.

As far as control screening tests are concerned, reactive and nonreactive 
control sera were required to reproduce the reactive and nonreactive results in all daily routines.

External evaluation of laboratory performance. There were two kinds of external quality control: 1) proficiency tests with unknown control sera panels as recommended by the World Health Organization (WHO) $(22,24)$, and 2) confirmation of results of sera submitted to the NRC by participating laboratories.

Proficiency tests. To conceal their identity, participating laboratories were identified by code numbers. Each laboratory received results of the overall analysis as well as an individual report, together with suitable recommendations. The probable sources of error and implementation of corrective measures were discussed in several workshops (Figure 1).

Participating laboratories were divided into two groups according to their function and the reagents used. Group 1 included laboratories performing serologic diagnosis with two quantitative tests using reagents manufactured by the NRC. Group 2 included those laboratories that performed blood banks controls with commercial screening kits. Both groups received two to four lyophilized control serum samples (27) to be included in the routine serologic analysis.

The results were analyzed for agreement, and a kappa index was calculated for each control (28).

Analytical methods and reagents. The following quantitative analytical methods were used for Group 1 laboratories: IHA (12), IIF (13), and ELISA (15), with antigens obtained from cultured epimastigotes of T. cruzi (Tulahuen strain). These tests were performed with reagents produced and controlled by the NRC as described (12) and were used by all participating laboratories in Group 1.

The laboratories in Group 2 performed the screening in blood banks
FIGURE 1. Proficiency testing of serum panels

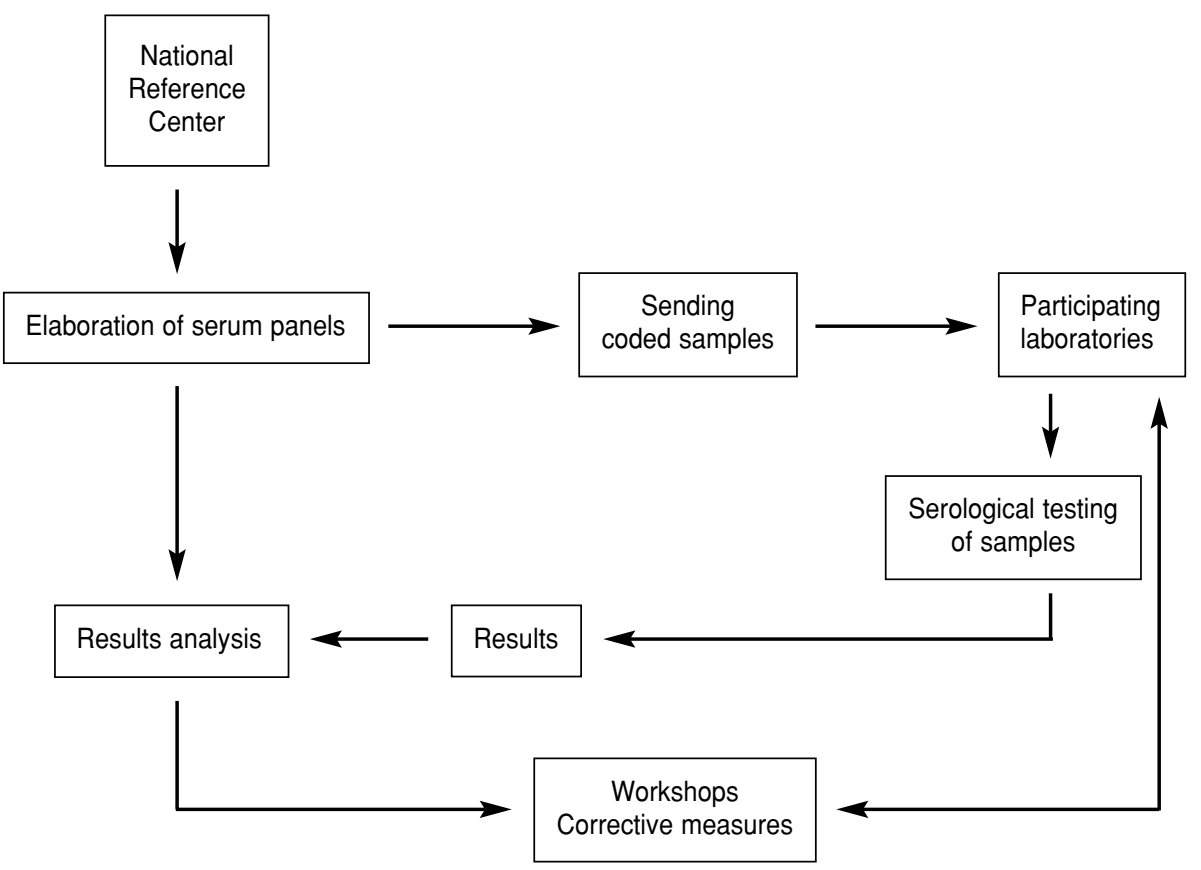

with the following qualitative tests: IHA, DA, and latex agglutination (16), with commercially obtained diagnostic kits. The following commercial kits were used: IHA was from Biocientífica S.A. Argentina, Polychaco S.A.I.C. Argentina, and Wiener Lab. Argentina; DA was from Polychaco S.A.I.C. Argentina and Wiener

Lab. Argentina; and latex was from Polychaco S.A.I.C. Argentina and Wiener Lab. Argentina.

\section{RESULTS}

Tables 1 and 2 show the results obtained with proficiency tests per-

TABLE 1. Proficiency tests performed in 1988-1994 by Group 1 laboratories of the Chagas' disease laboratory network in Argentina, with agreement of results obtained by using the indirect hemagglutination method to test control serum samples

\begin{tabular}{lccccc}
\hline \multicolumn{5}{c}{ Control serum samples } \\
\cline { 2 - 5 } Year & $\begin{array}{l}\text { Participating } \\
\text { laboratories }\end{array}$ & HR & WR & NR & Kappa index \\
\hline 1988 & 21 & $21 / 21$ & $18 / 21$ & $36 / 42$ & 0.71 \\
1989 & 24 & $24 / 24$ & $21 / 24$ & $48 / 48$ & 0.75 \\
1990 & 32 & $32 / 32$ & $30 / 32$ & $64 / 64$ & 0.95 \\
1991 & 29 & ND & $28 / 29$ & $29 / 29$ & 0.97 \\
1992 & 25 & ND & $25 / 25$ & $25 / 25$ & 1.00 \\
1993 & 20 & ND & $19 / 20$ & $18 / 20$ & 0.86 \\
1994 & 32 & $32 / 32$ & $32 / 32$ & $63 / 64$ & 0.98 \\
\hline
\end{tabular}

Note: Agreements: samples giving results within the permitted range and nonreactive (NR) samples. Kappa index was calculated with results of weakly reactive (WR) and NR sera. HR, highly reactive; ND, not done. 
TABLE 2. Proficiency tests performed in the period 1988-1994 by Group 1 laboratories of the Chagas' disease network in Argentina, with agreement of results obtained by using indirect immunofluorescence and enzyme-linked immunosorbent assay (ELISA) ${ }^{\mathrm{a}}$ to test control serum samples

\begin{tabular}{lccccc}
\hline & \multicolumn{5}{c}{ Control serum samples } \\
\cline { 2 - 6 } Year & $\begin{array}{l}\text { Participating } \\
\text { laboratories }\end{array}$ & HR & WR & NR & Kappa index \\
\hline 1988 & 21 & $21 / 21$ & $20 / 21$ & $33 / 42$ & 0.68 \\
1989 & 20 & $20 / 20$ & $20 / 20$ & $40 / 40$ & 1.00 \\
1990 & 28 & $28 / 28$ & $27 / 28$ & $55 / 56$ & 0.95 \\
1991 & 24 & ND & $24 / 24$ & $24 / 24$ & 1.00 \\
1992 & 22 & ND & $22 / 22$ & $22 / 22$ & 1.00 \\
1993 & 18 & ND & $18 / 18$ & $17 / 18$ & 0.94 \\
1994 & 17 & $17 / 17$ & $17 / 17$ & $33 / 34$ & 0.96 \\
\hline
\end{tabular}

${ }^{\text {a }}$ Results for 1994 correspond to ELISA.

Note: Agreements: samples giving results within the permitted range and nonreactive (NR) samples. Kappa index was calculated with results of weakly reactive (WR) and NR sera. HR, highly reactive; ND, not done. formed by Group 1 laboratories during the period 1988-1994 with IHA, IIF, and ELISA. For highly reactive samples, no false-negative results were reported in any of the control tests. However, false-negative results occurred with IHA and IIF for the weakly reactive control samples. With regard to nonreactive sera, a low proportion of false-positive results was reported: 6/42 for IHA and 9/42 for IIF during the first control test in 1988 and $2 / 20$ for IHA and $1 / 18$ for IIF in
1993. The kappa index value showed an apparent decrease in the number of false-negative results over a period of years as a result of the corrective measures undertaken by this group of laboratories.

Results of the analysis by the National Institute for Research on the Epidemiology of Chagas' Disease (Instituto Nacional de Investigación Epidemiológica del Chagas) of the serum panels selected, conditioned, and shipped by Group 1 laboratories are shown in
TABLE 3. Agreement of results of serum panels submitted by Group 1 laboratories to the NRC of Chagas' disease serologic diagnosis in Argentina, with the number of serum samples in each panel ranging from 40 to 100

\begin{tabular}{|c|c|c|c|c|}
\hline & & \multicolumn{3}{|c|}{ Year } \\
\hline & & 1989 & 1990 & 1994 \\
\hline $\begin{array}{l}\text { Participating laboratories } \\
\text { Serologic tests performed } \\
\text { Laboratories submitting serum }\end{array}$ & & $\begin{array}{l}31 \\
I H A^{a}-I I F^{b}\end{array}$ & $\begin{array}{c}35 \\
I H A-I I F\end{array}$ & $\begin{array}{l}32 \\
\text { IHA-ELISAC }\end{array}$ \\
\hline panels adequate for diagnosis/total & & $14 / 28$ & $25 / 30$ & $19 / 21$ \\
\hline $\begin{array}{l}\text { Laboratories with } 100 \% \\
\text { agreement of results }\end{array}$ & $\begin{array}{l}\text { Non-reactive samples } \\
\text { Reactive samples }\end{array}$ & $\begin{array}{r}6 \\
10\end{array}$ & $\begin{array}{l}19 \\
13\end{array}$ & $\begin{array}{l}18 \\
12\end{array}$ \\
\hline $\begin{array}{l}\text { Laboratories with } 99-80 \% \\
\text { agreement of results }\end{array}$ & $\begin{array}{l}\text { Non-reactive samples } \\
\text { Reactive samples }\end{array}$ & $\begin{array}{l}6 \\
4\end{array}$ & $\begin{array}{r}6 \\
12\end{array}$ & $\begin{array}{l}1 \\
6\end{array}$ \\
\hline $\begin{array}{l}\text { Laboratories with } 79-75 \% \\
\text { agreement of results }\end{array}$ & $\begin{array}{l}\text { Non-reactive samples } \\
\text { Reactive samples }\end{array}$ & $\begin{array}{c}2 \\
\ldots\end{array}$ & $\begin{array}{l}\cdots \\
\cdots\end{array}$ & $\begin{array}{c}\cdots \\
1\end{array}$ \\
\hline
\end{tabular}

Table 3. In nonreactive serum panels, in which no discordant results are permitted, there was a decrease from six to one discordant results in 1994, with respect to previous years, because of the use of corrective measures.

In $1989,50 \%$ of the laboratories submitted serum panels suitable for diagnosis; this proportion improved to 25/30 of the laboratories in 1990 and to 19/21 in 1994 (Table 3). Nearly 30\% of the shipments were scored as "very good" in the three controls.

The results of testing the proficiency of the blood bank screening tests (Group 2 laboratories) are shown in Figure 2. Results were grouped by the analytical method. A large variation was observed between the results of IHA and the other tests. In all laboratories, IHA performed better than the three other serologic methods used during the 3-year study (1988-1990).

\section{DISCUSSION}

The external evaluation results presented here for two groups of laboratories performing serologic tests for the diagnosis of T. cruzi infection reveal a progressive increase in the rate of agreement of results since the program was implemented. Group 1 was composed of the main laboratories scattered throughout the country and used the NRC as a unique source of reagents. Sources of diagnostic error at the start of the program could be explained by lack of standardization of procedures in participating laboratories. On the other hand, laboratories belonging to Group 2 were in the same city and chose their own reagents. Possible causes of error were discussed among all participants, and corrective measures were introduced, such as use of two tests in each laboratory, personnel training, and routine use of control sera.

Laboratory performance improved after coordinated work and the application of corrective measures based primarily on the installation of an internal quality control system. This process resulted from participating activi- 
FIGURE 2. External quality control of 19 blood bank laboratories of Argentina using commercial screening tests for Chagas' disease. Results of serum samples are grouped according to analytical method
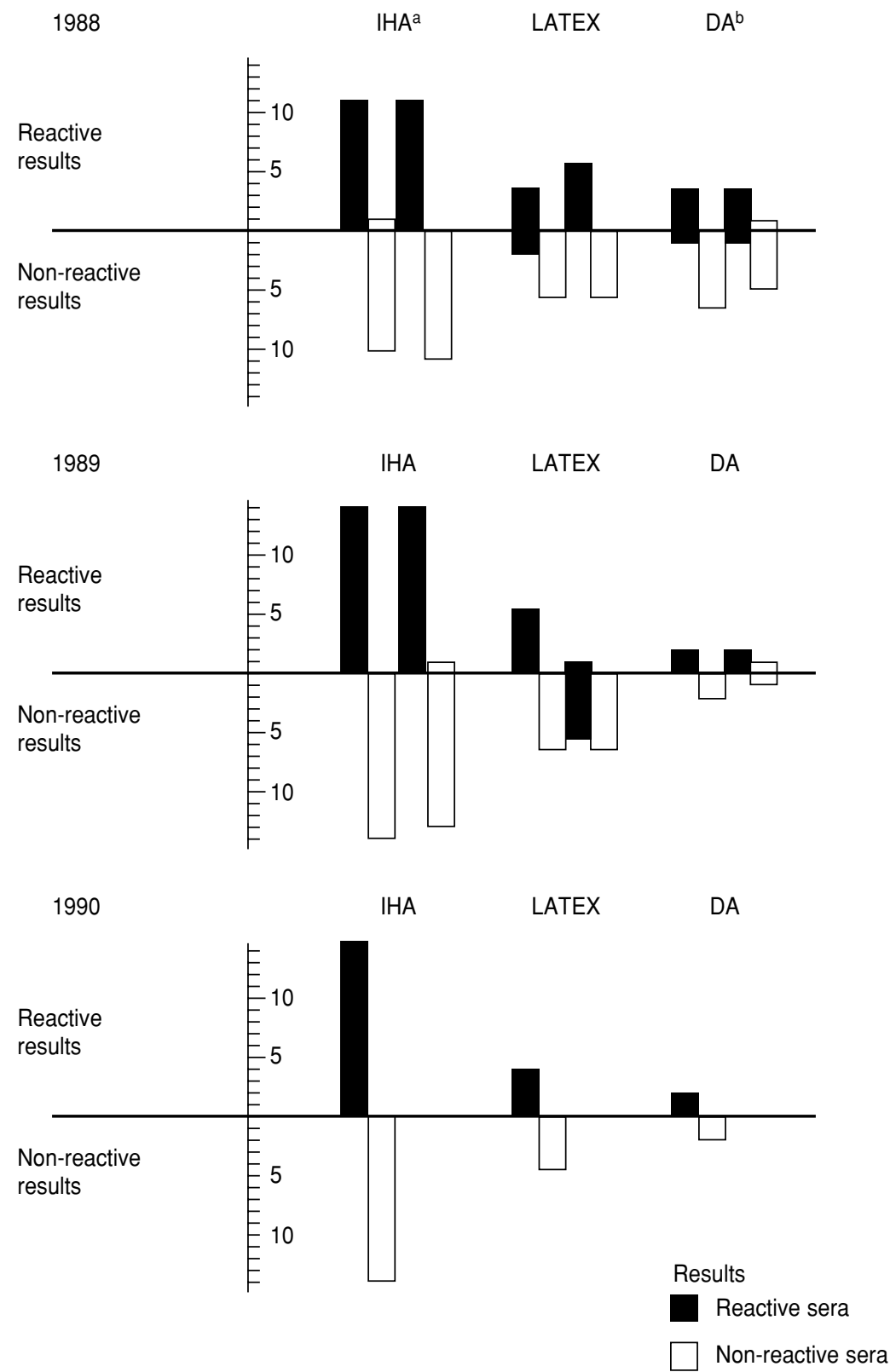

a IHA = Indirect hemagglutination.

${ }^{b} \mathrm{DA}=$ Direct agglutination. education is of paramount importance in this system $(24,26)$. As reported, these steps help avoid an important source of error, namely deficiencies in technical performance (29).

A collaborative study carried out by WHO throughout the Americas in 1983 (20) compared the results of Chagas' disease serodiagnosis obtained by several laboratories with serum panels from the endemic areas of the continent. Differences among assays as well as in the criteria about endpoint readings were found. Difficulties were attributed mainly to the absence of definite reference criteria as well as to variations among reagents and techniques (20).

Laboratory diagnosis of Chagas' disease in Argentina has been normalized; thus, at least two standardized serologic tests are now available (19). However, many factors affect the reliability of serologic results, as well as of those obtained by other analytical methods $(21,22)$. Development and improvement of reagents and techniques are a key to obtaining the most accurate diagnosis $(15,17)$. However, to obtain reproducible results by indirect diagnosis, it is necessary for all laboratories involved to use validated and controlled kits as well as standardized diagnostic procedures $(10,16,19)$. The only way to guarantee results appears to be by systematic installation of internal and external quality controls $(21,22)$, which has thus become the objective of our study.

Quality control systems have been recommended by WHO for health laboratories performing serologic tests $(21,24)$, and they are widely used in clinical chemistry (22). To detect and correct areas where errors might arise, proficiency testing programs provide a convenient way to check the performance of laboratories by comparing results obtained with the same samples. These external quality control programs for serologic tests used to diagnose conditions other than Chagas' disease have been established in some countries, such as France (30), Germany (31), and the United States (32). practices, was distributed and discussed during the workshops. As in other programs, the importance of personnel training and continuing supervision by the NRC. Moreover, a guideline of quality control procedures (23), including good laboratory 


\section{REFERENCES}

1. World Health Organization. Control of Chagas' disease. Technical report series no 811. Geneva: WHO; 1991:1-95.

2. Schmunis GA. Trypanosoma cruzi, the etiologic agent of Chagas' disease: status in the blood supply in endemic and nonendemic countries [review]. Transfusion 1991;31:547-557.

3. Schmunis GA, Szarfman A, Coarasa L, Guilleron C, Peralta JM. Anti-Trypanosoma cruzi agglutinins in acute human Chagas' disease. J Trop Med Hygiene 1980;19:170-178.

4. Blanco SB, Cura EN, Tulián L, Chuit R, Hurvitz A, Villalonga $\mathrm{C}$, et al. Detección de la madre y el niño chagásico en la transmisión materno infantil. Medicina (B Aires) 1993;53 (suppl 1):44.

5. Riarte A, Lauricella M, Campanini A, Sinagra A, Lansetti JC, Alvarez M, et al. Transmisión de la infección por T. cruzi mediante transplante renal. Evolución y tratamiento. Medicina (B Aires) 1993;53(suppl 1):78.

6. Segura EL. Xenodiagnosis. In: Brener RR, Stoka AM, eds. Chagas' disease vectors. Volume II: Anatomic and physiological aspects. Boca Raton, FL: CRC Press; 1987. p. 41-45.

7. Strout RG. A method for concentrating hemoflagellates. J Parasitol 1962;48:100.

8. Avila HA, Borges Pereira J, Thiemann O, De Paiva E, Degrave W, Morel CM, et al. Detection of Trypanosoma cruzi in blood specimens of chronic chagasic patients by polymerase chain reaction amplification of kinetoplast minicircle DNA: comparison with serology and xenodiagnosis. J Clin Microbiol 1993;31: 2421-2426.

9. Camargo ME. An appraisal of Chagas disease serodiagnosis. In: Wendel $\mathrm{S}$, Brener $\mathrm{Z}, \mathrm{Ca}-$ margo ME, Rassi A, eds. Chagas disease (American trypanosomiasis): its impact on transfusion and clinical medicine. São Paulo, Brazil: Cartgraf; 1992. p. 165-178

10. Cura EN, de Titto EH, Segura EL. El diagnóstico y su control de calidad en la infección por T. cruzi. In: Madoeri RJ, Madoeri C, Cámera MI, eds. Actualizaciones en la enfermedad de Chagas. Córdoba, Argentina: Organismo Oficial del Congreso Nacional de Medicina; 1992. p. $125-132$.

11. Rosenbaum M, Cerisola JA. La reacción de fijación del complemento para el diagnóstico de la enfermedad de Chagas. I. Técnica. Prensa Medica Argentina 1958;45:1551-1560.

12. Instituto Nacional de Chagas. Actualización en enfermedad de Chagas y otras parasitosis.
In: Manual de Laboratorio, 7th ed. Buenos Aires, Argentina: Instituto Nacional de Chagas; 1994. p. 1-90.

13. Alvarez M, Cerisola JA, Roweder RW. (1968). Test de inmunofluorescencia para el diagnóstico de la enfermedad de Chagas. Bol Chil Parasitol 1968;23:4-9.

14. Camargo ME, Ferreira WA, Peres BA, Previato LM, Sharfstein J. Trypanosoma cruzi antibodies. In: Methods of enzymatic analysis. Volume XI: Antigens and antibodies 2, 3rd ed. Weinheim, Federal Republic of Germany: Bergmeyer VCH Verlagsgesellschaft $\mathrm{mbH}$ D-6940; 1986. p. 368-382.

15. Cura EN, Ruíz AM, Velázquez E, Malagrino N, Örn A, Segura EL. Estandarización de un kit confirmación (FATALAKIT) para el inmunodiagnóstico de la infección por el Trypanosoma cruzi. Medicina (B Aires) 1993;53(suppl 1):182.

16. Guimaraes MCS. Chagas' disease serology. In Pan American Health Organization/World Health Organization, ed. Specifications and evaluations methods for immunological reagents. Washington, DC: PAHO/WHO; 1984. p. 1-153. (PNSP/84-08).

17. Simonsen Stolf AM. Trypanosoma cruzi antigens in serodiagnosis. In: Wendel S, Brener Z, Camargo ME, Rassi A, eds. Chagas disease (American trypanosomiasis): its impact on transfusion and clinical medicine. São Paulo, Brazil: Cartgraf; 1992. p. 195-202.

18. Wendell S, Gonzaga AL. Chagas' disease and blood transfusion: a new world problem? Vox Sang 1993;64:1-12.

19. Ministerio de Salud y Acción Social. Normas para el Diagnóstico de la Infección Chagásica. Resolución Ministerio Salud y Acción Social no. 2373. Ley no. 22360 de la República Argentina; 1988

20. Camargo ME, Segura EL, Kagan IG, Pacheco Souza JM, de Rocha Cavalheiro J, Yanousky JF, et al. Three years of collaboration of the standardization of Chagas' disease serodiagnosis in the Americas: an appraisal. Bull Pan Am Health Organ 1986;20:233-244.

21. Taylor RN, Huong AY, Fulford KM, Przybyszwski VA, Hearn TL. In: Centers for Disease Control, ed. Control de calidad de las pruebas inmunológicas. Atlanta, GA: Centers for Disease Control; 1979. p. 1-105. (Publication no. CDC 798376)

22. Uldall A. Quality assurance in clinical chemistry. Scand J Clin Lab Invest 1987;47 (Suppl 187):1-96.
23. Cura EN, de Titto EH, Segura EL. Control de calidad del inmunodiagnóstico de Chagas. In: Instituto Nacional de Investigación Epidemiológica del Chagas. Manual de procedimientos. Buenos Aires, Argentina: INDIECH; 1992. p. $1-43$.

24. World Health Organization, ed. External quality assessment of health laboratories. Geneva: WHO; 1981:1-23. (Euro Reports and Study no 36).

25. Subias E, Yanovsky J, Alvarez M, Segura EL. Conservation of blood samples for epidemiological research on Chagas' disease [abstract]. J Protozool 1983;30:164

26. Taylor RN. Measurement of variation and significance in serological tests. Ann N Y Acad Sci 1983;420:13-21.

27. Uldall A. Practical aspects of internal quality assurance. Ann Ist Super Sanid 1991;2:411-418.

28. Riegelman RK, Hirsch RP. Cómo estudiar un estudio y probar una prueba: lectura crítica de la literatura médica, 2nd ed. Washington, DC: Organización Panamericana de la Salud; 1992. (Publicación científica 531).

29. Heier HE, Kornstad L. External national quality control of blood typing 1983-92. Significance for quality assurance in transfusion medicine. Tidsskr Nor Laegeforen 1993;113: 3155-3158.

30. Petithory JC. Organization and interest of external quality assesment in parasitology. Arabian J Lab Med 1988;14:145-146.

31. Janitschke K, Seitz HM, Disko R. External quality assurance in the laboratory diagnosis of parasitic infections in Germany. Med Microbiol Lett 1994:3:272-278.

32. Taylor RN, Fulford KM. Assesment of laboratory improvement by the Centers for Disease Control diagnostic immunology proficiency testing program. I Clin Microbiol 1981;13: 356-368.

Manuscript received on 21 August 1996. Revised version accepted for publication on 27 October 1997. 
RESUMEN El Centro Nacional de Referencia ha llevado a cabo desde 1988 un programa de garantía de calidad en la red de laboratorios para el diagnóstico de la enfermedad de Chagas en Argentina. El propósito ha sido evaluar la confiabilidad de los resultados de la prueba serológica. La enfermedad de Chagas es endémica en Argentina, pero la prevalencia de seropositividad a Trypanosoma cruzi en hombres de 18 a 24 años bajó de $5,8 \%$ en 1981 a 1,8\% en 1994. Alrededor de 600 laboratorios forman la red para el diagnóstico de la enfermedad de Chagas, que cuenta con un laboratorio central en cada una de las 24 provincias argentinas. El programa para la garantía de la calidad promueve la aplicación continua de las buenas prácticas de laboratorio y se vale de controles de calidad internos y externos para mejorar el rendimiento de los participantes. También provee asistencia técnica y sienta parámetros normativos. Cualquier enmienda que resulte necesaria se discute en talleres de trabajo. Los resultados de la primera evaluación externa en que investigó la exactitud de las pruebas serológicas y la confirmación de los resultados obtenidos en 58 de los principales laboratorios revelan que de 1988 a 1994 la tasa de concordancia mejoró.

Garantía de calidad en el
diagnóstico serológico de la
enfermedad de Chagas

$\begin{gathered}\text { V Curso-taller OPS/OMS-CIESS sobre Legislación de la Salud: } \\ \text { problemas emergentes de IoS procesos de cambio II }\end{gathered}$
Fechas: 31 de agosto a 4 de septiembre de 1998
Lugar: $\quad$ México, D.F., México
La División Jurídico Social del Centro Interamericano de Estudios de Seguridad Social
(CIESS) y la División de Salud y Desarrollo Humano de la OPS organizan este taller que pre-
tende abrir un espacio docente en el que se pueda discutir el marco regulatorio del finan-
ciamiento de la salud y la seguridad social. Entre las variables de análisis y debate se conside-
rarán los regímenes contributivos y no contributivos, las dicotomías creadas entre los diversos
actores por los modelos actualmente en vigencia, las personas en quienes recae con frecuen-
cia el subsidio, la concertación intersectorial y la conservación de derechos en el tránsito entre
sistemas, así como la necesidad de rescatar los componentes de equidad y eficiencia en el
entendido de que son principios no excluyentes, sino complementarios.
Información:
CIESS
División Jurídico Social
Fax: (525) 595-06-44
0
Organización Panamericana de la Salud
División de Salud y Desarrollo Humano
525 Twenty-third Street, NW
Washington, DC 20237, EUA

